\title{
Model of Translating Preposition (MTP) of Arabic into Malay
}

\author{
Azman Che Mat \\ Universiti Teknologi MARA (UiTM) Dungun, Terengganu, Malaysia \\ azman531@tganu.uitm.edu.my
}

\section{Doi:10.5901/mjss.2014.v5n23p2420}

\begin{abstract}
Arab scholars have categorized Arabic language into three, noun, verb and functional word. Each category bears semantic value that will need specific scrutiny. This article investigates particle use of Arabic preposition as a part of functional word, and proposes a method for accurate translation. Syntactic and semantic aspects are prime needs that must be put into account for Arabic translation into Malay. Apart from that, lexical meaning alone is inadequate to render preposition of Arabic into Malay. Phrasal meaning and contextual meaning were also must be considered in preposition use of Arabic because they can create a difference semantically. Thus this article as well will analyze functional aspects of preposition based on lexical, phrasal and contextual levels when translating Arabic text into Malay.
\end{abstract}

Keywords: preposition, translation, functional, Arabic, Malay

\section{Introduction}

Translation is an important field of knowledge to develop a human civilization. Translation process involving two languages, namely source language and target language. By that way, the skills of both different languages are greatly required. Verbal skills meant must be cover linguistic aspects and sociolinguistics. There is no doubt that difference between languages may drive translator to be forced to paraphrase such meaning that does not possessed by the target language.

Through several studies that were carried out on Arabic language (AL) and Malay language (ML), visibly that there are a few similar aspects between both languages. Obviously, similar aspect was preposition category. In Arabic, preposition was known as jarr's letter. This category is having a set of some remarks counted as preposition, also like Malay language which categorizes certain functional words as preposition.

This article will shed a light on translation aspects occur in preposition of Arabic as source language, and Malay language as target language. It suffuses lexical meaning of each words and phrase meaning occur in Arabic language grammar.

\section{Definition}

Preposition in AL has several definitions according to different grammarians' scholars. Obviously, each proposed definition is founded by preposition function. For instance, al-Daqar (1993: 24) and Yacqūb (1996: 551) define "it is something that gives meaning but not understood separately from phrase or sentence." According to Ibn Sĩdah (nd: 44), "preposition was which connects between noun with verb, noun with noun and explaining reason communed."

As so the definition of preposition for ML has no difference. According to Za'ba's (1965: 177) "preposition is specific words dressed with name or pronoun only to show the connection of name or the pronoun or pronoun withsomething other word in the sentence." Nik Safiah Karim et al. (1996: 252) define "preposition was particle which situated before noun phrase." Prepositions are divided into two; namely a function for showing something place or still and indicating direction or movement (Abdullah Hassan 1998: 153),

The given definition in $A L$ and $M L$ preposition has similarity from functional aspect. The function of preposition is to communicate meaning between noun with noun or nominal phrase with nominal phrase and further. This equivalent to some extent will help translation process from AL into ML. 


\section{Translating Preposition from AL to ML}

As preposition is lexical element which frequently used in Arabic, then it use must be understood by translator. Indeed literal translation can be done towards Arabic to Malay language in certain circumstances. However translation on lexical level alone is not enough to produce 'quality translation.' By that way, other aspect such as preposition use in certain context and phrasal preposition (collocation) also giving different meanings to particular preposition.

\subsection{Translation at lexical level}

Basically, each of AL prepositions could be translated literally or "word to word" into ML in certain context. In this level, preposition meaning and function may be said almost fully equivalence in both languages. Example may be made is like following:

1. Particle الباء substitutes to particle dengan (with) such as:

Arabic: رسم فريد الصورة بالمرسم (Farid draw with pencil)

Malay: Farid melukis potret dengan pensel

2. Particle subtitutes to particle dari, daripada (from/of) such as:

Arabic: ذلك النحت صنع من الحديد (The carving is made from metal)

Malay: Ukiran itu diperbuat daripada besi

Arabic: تهب العاصفة من الجنوب (the storm blows from south)

Malay: Angin kencang bertiup dari selatan

Arabic: يبدأ الاجتماع من الساعة الر ابعة و النصف إلى الساعة الخامسة و النصف (the meeting starts from 4.30 pm to 5.30 pm.)

Malay: Mesyuarat akan bermula dari 4.30 hingga 5.30.

3. Particle إلى substitutes to particle ke, kepada (to) such as:

Arabic: قاد عادوا إلى القرية(They went back to hometown)

Malay: Mereka sudah pulang ke kampung

Arabic: اعطى هذه الرسالة إلى و الدك (Give this letter to your father)

Malay: Berikan surat ini kepada ayah awak

4. Particle حتى substitutes sehingga (until) as below:

Arabic: يتلون القرأن الكريم حتى العصر (They recite al-Quran until evening)

Malay: Mereka membaca al-Quran hingga/sampai waktu asar

Lexical meaning of preposition can be found easily in dictionary or thesaurus. Frequently use of the lexical meaning for translation may not accurate in certain context and in different texts and registers used by writer. The following paragraph deals with phrasal meaning of Arabic preposition.

\subsection{Translation at phrasal level}

There are a few Arabic prepositions which can give a large difference on lexical meaning. According to Arabic grammar, the school of thought known as al-Madrasah al-Kufiyyah has proposed homonym concept for preposition use. They asserted such preposition can give meaning apart from its original meaning (Hassan 1982: 12). Therefore, certain preposition may replace to another as the table 3.2 demonstrates:

Table 3.2a: Preposition with homonym concept

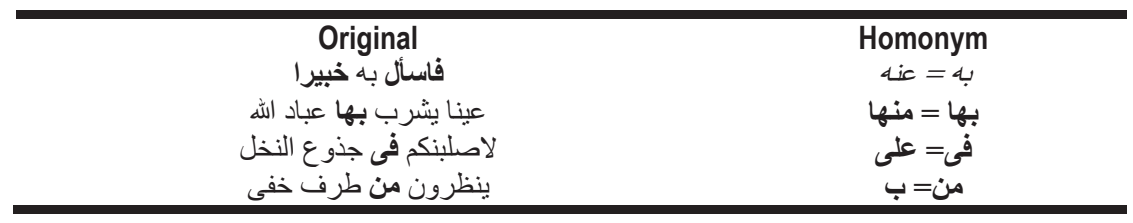

Source: "Tanāwub Huruf al-Jarr fi Lughat al-Qurān" by Prof. Dr. Hassan cAwwād

The table 3.2a above demonstrates how prepositions may share the same meaning/function. This is as well accepted among Arabic linguists like al-Murādi (2008), al-Suyūți (1998) and Ibn Hishām (1996). From the translation perspective, 
understanding this feature is perusal and making a right equivalent is required. The examples below show how the translation was done successfully:

1. Particle الباء preceded by عن:

Arabic: فاسأل به خبير (so ask about Him someone who knows)

Malay: maka bertanyalah akan hal itu kepada yang mengetahuinya

2. Particle من preceded by:

Arabic:عينا يشرب بها عباد الله (that will be spring from which Allah's servants will drink)

Malay: laitu sebuah matair (di Syurga), yang diminum daripadanya oleh hamba-hamba Allah (yang taat)

3. Particle في preceded by على

Arabic:and will crucify you on the trunks of palm-trees)

Malay: dan Aku akan memalang kamu atas batang-batang pohon tamar;

4. Particle si preceded by الباء:

Arabic:ينظرون من طرف خفى (looking with stealthy glance)

Malay: sambil memandang (ke neraka itu) hanya dengan mengerling (kerana gerun takut)

While al-Madrasah al-Bașriyyah another school of thought has rejected this concept, and proposed a concept of taḍinn. That is, exegesis or other interpretation is required if equation between different preposition is found. Hassan (1989: 5) mentioned this phenomenon happened because of strong desire among theologians to keep language in harmony.

Table 3.2b: Preposition with tadmin concept

\begin{tabular}{|c|c|}
\hline 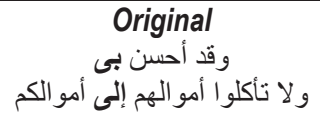 & و لا تضمو ها إليها آكلين \\
\hline
\end{tabular}

Source: "Tanāwub Huruf al-Jarr fi Lughat al-Qurān" by Prof. Dr. Hassan 'Awwād.

This concept is categorized as samāci where the exact meaning only obtained through native speaker speech Arabic and had no specific method (al-Daqar 1993: 162). Therefore this concept is not possible to apply on the translator who is not a native speaker of Arabic. Otherwise if he has a long experience with Arabic use and gained a broad knowledge of samāci, it can be adopted in his translation process.

\subsection{Translation at contextual level (collocation)}

Translating preposition in contextual level is challenging as well, especially the use of a fix arrangement called collocation. With unchanged combination of words, this phrase structure will give its own meaning within a contextual use. By that way, translation does according simply to lexical meaning, doubtless will raise inaccurate translation. Translator must be sensitive of this collocation in sentence and text as follow:

Table 3.3: Preposition as collocation

\begin{tabular}{|c|c|}
\hline 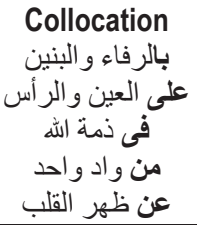 & $\begin{array}{c}\text { Literal translation } \\
\text { Dengan kesenangan dan anak-anak } \\
\text { Atas mata dan kepala } \\
\text { Dalam janji Allah } \\
\text { Dari satu wadi/ lembah } \\
\text { Dari belakang hati }\end{array}$ \\
\hline
\end{tabular}

Source: "al-Mucjam al-Siyāai" by Mahmud al-Ṣini.

As mentioned by Ghazalla (2008), many collocations are two words each and play a vital role in language. The combination of preposition with noun as shown in the above is part of collocation. It is possible to find collocation of verb with preposition such رغب في and Arabic language, but this paper will not discuss it for limitation reason. As 
suggested by Dickins et al. (2002) the translator has to be able to recognize and render source text with collocative meaning.

Some collocation of preposition may appear as proverb or idiom in Arabic. If the matter is so, translator is recommended to find the appropriate denotative meaning of Arabic language. The example below will demonstrate contextual translation of preposition:

1. Particle الباء:

Arabic:بالرفاء و البنين (Happy marriage)

Malay: Selamat pengantin baru

2. Particle على:

(Mrabic: على العين و الر أس (My pleasure)

Malay: Dengan senang hati

3. Particle في في :

في ذمة ال山:Aabsed away)

Malay: Meninggal dunia

4. Particle من:

Arabic:من و اد واحن (same race)

Malay: Satu negeri/satu daerah/satu kampung/satu bangsa/satu keturunan

5. Particle عن:

Arabic: عن ظهر القلب (Memorizing)

Malay: Tanpa hafalan

Collocative meaning with preposition as well can be found in Malay but with different structure. These examples are rendered with 'Selamat pengantin baru', 'Meninggal dunia', 'Satu negeri' and 'Tanpa hafalan' where no prepositions have in use. However it is possible that preposition is used in both languages with their collocative meaning such as the second example has shown 'Dengan senang hati.'

\subsection{Exception}

The use of preposition in Arabic has specific function known as zāidah (additional preposition). This function is used to give affirmation of the phrase or sentence. Although the fundamental inflection marker is still applied, it's semantically giving additional meaning to phrase or sentence. The sentence with this feature can be rendered with auxiliary word to denote affirmation in Malay like examples below:

1. Particle الباء:

Arabic: ما أنا براض على تصرفاء (I'm really unsatisfied with your attitude)

Malay: Saya amat tidak reda dengan perlakuan kamu

2. Particle الكاف:

Arabic:لست كمثل الأخرين (You are absolutely not like other)

Malay: Kamu benar-benar bukan seperti mereka

The word amat, sungguh, benar-benar etc. in Malay can help translator to give affirmation meaning when used appropriately. In this sense, literal translation of preposition will produce weird translation as follow:

1. 'Saya tidak dengan reda dengan perlakuan kamu' retranslate as (I'm with unsatisfied with your attitude)

2. 'Kamu bukan bagai seperti mereka' retranslate as (I'm not as like them)

\section{Conclusion}

Based on analysis was being conducted above, it can be concluded that preposition use in Arabic should be given specific attention in translating text. Although most prepositions of Arabic could be translated literally into preposition of Malay language, however it is very necessary for translator to understand every particle use in various language styles.

Based on the analysis, we are able to come up with a model of methods to render each these particles in Arabic. The model is illustrated in the figure 1 As follows: 


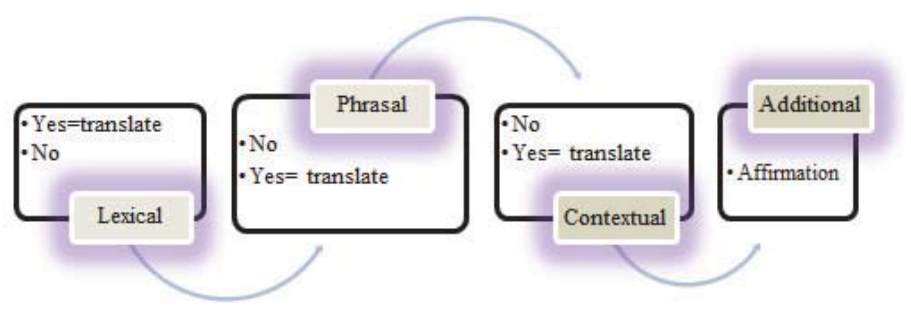

Figure 1: Model of Translating Preposition (MTP) of Arabic into Malay

Thus, prepositions are special whose meanings are negotiable depend to their constituents in the text. Their most special and essential component is collocation, namely, their contextual aspect. Hence its crucial importance in translation, to the extent that the success of a translation of the preposition stands with the degree to which lexical is retained or phrasal, contextual and additional are distorted.

In teaching and learning process, giving exposure to students with various examples may help them to understand the functional of preposition in Arabic discourse. As mentioned by Azman (2012), translation of Arabic language needs student to be creative in transferring and reconstructing of TL. It's worthwhile giving student the model of translating preposition (MTP) to help them finding appropriate meaning of preposition in different genres of Arabic text. In the translation practice, especially grammar structures, it is necessary to consider the factor including functional equivalence. That is because the Malay translation of preposition must be successful not only in form, but also in meaning (Azman, 2014).

\section{References}

Abdullah Hassan. (1996). Isu-isu pembelajaran dan pengajaran bahasa Melayu [Issues in learning and teaching of Malay language]. Kuala Lumpur: Dewan Bahasa dan Pustaka.

Al-Daqar, cAbd al-Ghanī. (1993). Mucjam al-qawācid al-Arabiyyah fi al-nahw wa al-sarf [Dictionary of Arabic grammar in syntax and morphology]. Dimashq: Dār al-Qalam.

Azman Che Mat. (2003). Kata sendi nama bahasa Arab dan bahasa Melayu: satu kajian perbandingan dari aspek tugas [Arabic and Malay prepositions: a contrastive study of functional aspect]. MA Dissertation at FPI, UKM, Bangi.

Mat, A. C., (2012). Conceptual Model of Translation Approach in Foreign Language Teaching and Learning. International Journal of Social Sciences \& Education, 2(3).

‘Awwād Hassan. (1982). Tanāwub hurūf al-jarr fi lughat al-Qur'an [Preposition's alternation in Quran's language]. Ammān:Dār al-Furqān. Dickins. J, Hervey. S \& Higgins. S. (2002). Thinking Arabic translation. London \& New York: Routledge

Ghazala, Hassan. (2008). Translation as problems and solutions. Beirut: Dār al-cilm lilmalāyīn.

Ibn Sīdah, Abū Hasan ‘Ali bin Ismācīl al-Andalūsī. (N.D). Al-mukhașșaș [Provision]. Vol. 2. Beirūt: Dār lḥyā’ al-Turāth al-cArabī.

Ismācil, Mahmud al-Șinī, (1996). al-Mucjam al-siyāqi li al-tacbirāt al-istilāhi [Contextual dictionary for expression]. Beirut: Maktabah Lubnān.

Mahmud Yunus, (1973). Qāmus ‘ Arabī-Indūnisī [Dictionary of Arabic-Indonesia]. Jakarta: Yayasan Penyelenggara Penterjemah.

Mat, A. C., Yaakub, A. M. N., \& Tajuddin, N. A. (2014). Translating Circumstantial Clause of Arabic into Malay. Asian Social Science, 10(13), p72.

Nik Safiah Karim, Farid M. Onn, Hasyim Hj. Musa \& Abdul Hamid Mahmood. (1996). Tatabahasa Dewan: Edisi Baru [Dewan's grammar: new edition]. Kuala Lumpur: Dewan Bahasa dan Pustaka.

Yacqūb, Imīl Badīc. (1996). Mawsūcah al-nahw wa al-sarf wa al-icrāb [Encyclopedia of syntax, morphology and icrab]. Beirūt: ār alMalāyīn. 